Original Research Article

\title{
Phytochemical evaluation and pharmacological screening of ethanolic and aqueous leaf extracts of Pupalia lappacea for antihyperlipidemic and antihyperglycemic activities in alloxan induced diabetic Albino wistar rats
}

\author{
Mehnoor Farheen ${ }^{1 *}$, Chakrapani Ramesh ${ }^{2}$
}

${ }^{1}$ Department of Pharmacology, Shadan Womens College of Pharmacy, Department of Pharmacology, Khairatabad, Hyderabad, Telangana, India ${ }^{2}$ Department of Pharmacology, Sai Pranavi College of Pharmacy, Keesara, Hyderabad, Telangana, India

Received: 30 January 2018

Accepted: 06 March 2018

*Correspondence to:

Dr. Mehnoor Farheen,

Email: mehnoorfarheen21@ gmail.com

Copyright: (C) the author(s), publisher and licensee Medip Academy. This is an openaccess article distributed under the terms of the Creative Commons Attribution NonCommercial License, which permits unrestricted noncommercial use, distribution, and reproduction in any medium, provided the original work is properly cited.

\begin{abstract}
Background: Diabetes is associated with damage to the liver, pancreas and kidney. The damage may vary among patients. This study assessed the hypoglycaemic and antihyperlipidemic activities of leaves ethanolic and aqueous extracts of Pupalia lappaceae in alloxan induced diabetic albino wistar rats.

Methods: There were Fifty four rats divided into nine groups containing six rats each. Group 1 consists of normal rats that were given only normal saline and served as a control group. Group 2 consists of normal rats that were given alloxan monohydrate $(150 \mathrm{mg} / \mathrm{kg}$ b.w). Group 3 consists alloxan induced diabetic rats that were given daily sterile solution. glibenclamide+simvastatin $(5 \mathrm{mg} / \mathrm{kg})$ Group 4 consists of alloxan induced diabetic rats that were given daily sterile solution, AEPL extract $(100 \mathrm{mg} / \mathrm{kg})$. Group 5 consists of alloxan induced diabetic rats that were given daily sterile solution, drug extract AEPL $(200 \mathrm{mg} / \mathrm{kg})$. Group 6 consists of alloxan induced diabetic rats that were given daily sterile solution, drug extract AEPL (400mg/kg) Group 7 consists of alloxan induced diabetic rats that were given daily sterile solution, drug extract EEPL (100mg/kg), Group 8 consists of alloxan induced diabetic rats that were given daily sterile solution, drug extract EEPL $(200 \mathrm{mg} / \mathrm{kg})$ Group 9 consists of alloxan induced diabetic rats that were given daily sterile solution, drug extract EEPL $(400 \mathrm{mg} / \mathrm{kg}$ respectively for 21 days by an intragastric tube with free access of food and water.

Results: Chemical composition of the plant was estimated by GCMS technique several biochemical parameters were assessed. Oral administration of the extract resulted in significant reduction in mean values of blood glucose, triglycerides, total cholesterol, cholesterol ratio, LDL, VLDL, accompanied by increase in the mean value of the HDL in diabetic rats and histopathology of liver, pancreas, and kidney showed significant changes.

Conclusions: The effects produced were closely similar to standard antidiabetic and antihyperlipidemic drug. It can thus be concluded that the ethanolic and aqueous extract of Pupalia lappaceae exhibit antihyperlipidemic and antihyperglycemic activities in alloxan induced diabetes in rats.
\end{abstract}

Keywords: Antidiabetic, Antihyperlipidemic, Alloxan, Pupalia lappaceae

\section{INTRODUCTION}

Research has shown that over $40 \%$ of plants comprise key ingredients which can be used for prescription drugs, and researchers look to traditional medicine as a guide to help them.
There are as many as one hundred and twenty compounds which have been taken from the higher plants, and 80 percent of those which are used in modern medicine have a positive connection between their There has been a resurgence of interest in herbal medicine interest in the past few years. ${ }^{1}$ There are a number advantages associated 
with using herbal medicines as opposed to pharmaceutical products. Reduced risk of side effects, Effectiveness with chronic conditions, Lower cost, Widespread availability. ${ }^{2}$ Pupalia lappacea is a very variable plant. It can be annual or perennial. The plant is sometimes harvested from the wild for local use, mainly as a medicine but also as a food. Widespread through Africa but avoiding the wettest regions; through tropical Asia to Philippines, New Guinea and Polynesia. Savannah and woodland localities and forest path sides.

The plant has a number of medicinal uses. The leaves are antitussive, diuretic and febrifuge. They are taken in various ways in the treatment of coughs. They are also used in various ways to treat dysenty, diarrhoea and oedema. The leaves are used in an enema to treat constipation. Applied externally, the leaves are mixed with palm-oil or butter for the treatment of boils. The leaves are also used in topical applications to treat cuts.

The crushed seeds are considered to be a good remedy for infected sores and ulcers. The root is antidote and purgative. It is used in the treatment of snakebites and syphilis.

The plant-ash is mixed with water and then drunk in the treatment of flatulence. The ashes mixed with water are applied to leprosy sores after they have been made to bleed. ${ }^{3,4}$

Diabetes mellitus (or diabetes) is a chronic, lifelong condition that affects your body's ability to use the energy found in food. There are three major types of diabetes: type 1 diabetes, type 2 diabetes, and gestational diabetes. Normally, the body breaks down the sugars and carbohydrates you eat into a special sugar called glucose. But the cells need insulin, a hormone, in the bloodstream in order to take in the glucose and use it for energy. ${ }^{5,6} \mathrm{With}$ diabetes mellitus, either the body doesn't make enough insulin, it can't use the insulin it does produce, or a combination of both. Since the cells can't take in the glucose, it builds up in the blood. High levels of blood glucose can damage the tiny blood vessels in the kidneys, heart, eyes, or nervous system. That's why diabetes especially if left untreated - can eventually cause heart disease, stroke, kidney disease, blindness, and nerve damage to nerves in the feet. ${ }^{7,8}$

Hyperlipidemia, hyperlipoproteinemia, is abnormally elevated levels of lipoproteins in the blood in the blood. It is the most common form of dyslipidemia. Hyperlipidemia is are divided into primary and secondary subtypes. Primary hyperlipidemia is usually due to genetic causes while secondary hyperlipidemia arises due to other underlying causes such as diabetes. ${ }^{9,10}$

The present study of the selected medicinal plants has been studied for its antidiabetic and antihyperlipidemic activity. As the leaves of the plant are rich in flavonoids the idea to do research about its anti-diabetic and hypolipidemic activity stemmed out.

The objective of the study includes:

- Collection and authentication of leaves of the selected plant.

- Preparation of ethanolic extract by maceration.

- Selection and grouping of animals.

- Induction of diabetes in rats by intraperitoneal injection of alloxan.

- Screening of antihyperglycemic and antihyperlipidemic activities of extracts of the medicinal plant.

Biochemical estimation of the selected plant on glucose level, triglycerides level, total cholesterol level, low density lipoprotein, high density lipoprotein, very lowdensity lipoprotein.

- $\quad$ Samples were analysed by GCMS analysis results were tabulated in Table 1.

- Histopathological studies of liver, pancreas and kidney were performed.

\section{METHODS}

\section{Collection of drugs}

Dried leaves of the plant were collected. The plant was taxonomically identified and authenticated by Dr.K. Madhava Chetty Assistant professor of Botany, Department of Pharmacognosy, Sri Venkateshwara University, Tirupati.

\section{Chemicals}

Ethanol, Distilled water, Alloxan monohydrate $150 \mathrm{mg} / \mathrm{kg}$ b.w, Glibenclamide, Simvastatin

\section{Preparation of plant extract}

The leaves of the plant were subjected to shade drying. On complete drying the leaves were powdered and stored in air tight containers at room temperature. The powder of leaves was macerated with ethanol and distilled water for 7 days and then filtered. The filtrate was evaporated to obtain dried extracts. The extracts obtained were subjected for evaluation of anti diabetic and anti hyperlipidaemic activity. The plant extract was prepared by maceration. The filtrate thus obtained was ethanolic extract and aqueous extract respectively (Figure 1).

\section{Preliminary phytochemical screening}

The extracts were tested for the presence of secondary metabolites like, flavanoides, alkaloides, saponins, glycosides, steroids, proteins etc. and the results were plotted in the Table $2 .{ }^{11}$ 


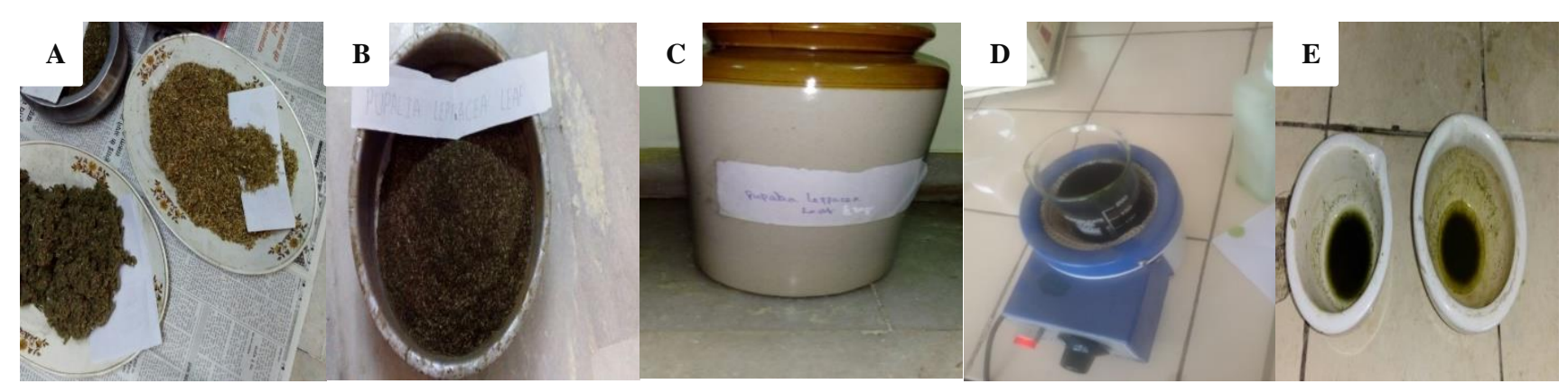

Figure 1 (A to E): Preparation of extract by maceration technique.

Table 1: Phytoconstituents of the extract.

\begin{tabular}{|ll|}
\hline Phytoconstituent & Amount \\
\hline Steroids & +++ \\
\hline Glycosides & +++ \\
\hline Saponins & ++ \\
\hline Alkaloids & +++ \\
\hline Sugar & ++ \\
\hline Phenol & + \\
\hline Tannins & - \\
\hline Flavanoides & +++ \\
\hline
\end{tabular}

Keys: $+++=$ appreciable amount, $++=$ moderate amount, $+=$ trace amount, $-=$ completely absent

\section{Toxicity study}

\section{Acute oral toxicity}

The acute oral toxicity studies of all the three extracts were undertaken as per the (OECD) guidelines for testing of chemicals by up-and-down procedure. The rats were fasted overnight, and the weight of each rat used was recorded just before use. Animals were divided randomly into a control and three treatment groups for each extract, each group consisting of four rats (two males and two females). Control group received only the vehicle and each treatment group received orally the AEPL and EEPL of the studied plant in the limit test at a rate of $2000 \mathrm{mg} / \mathrm{kg}$ body weight was conducted and terminated after four survivals out of four animals. Animals were kept under close observation for $4 \mathrm{~h}$ after administering the extracts, and then they were observed daily for 3 days for any change in general behavior and other physical activities and mortality. ${ }^{12}$

\section{Experimental animals}

Wistar albino rats (180-250 g) of both sexes were selected. Before and during the experiment rats were fed with standard diet. After randomization to various groups and before initiation of experiment, the rats were acclimatized for a period of 7 days under standard environmental conditions of temperature, relative humidity, and dark/light cycle.

\section{Experimental design}

- Group-I: Normal control rats received normal saline p.o

- Group-II: Diabetic control rats received alloxan $150 \mathrm{mg} / \mathrm{kg}$. b.w i.p

- Group-III: Diabetic rats treated with (glibenclamide+simvastatin) $5 \mathrm{mg} / \mathrm{kg}$.b.w p.o

- Group-IV: Diabetic rats treated with AEPL100mg/kg.b.w p.o

- Group-V: Diabetic rats treated with AEPL 200mg/kg.b.w p.o

- Group-VI: Diabetic rats treated with AEPL 400mg/kg.b.w p.o

- Group-VII: Diabetic rats treated with EEPL100mg/kg.b.w p.o

- Group-VIII: Diabetic rats treated with EEPL 200mg/kg.b.w p.o

- Group-IX: Diabetic rats treated with EEPL 400mg/kg.b.w p.o

The body weight gain and fasting BGL of all the rats were recorded at regular intervals during the experimental period. The BGL was monitored in the diabetic rats by tail tipping method.

\section{Preparation of drug solution}

Ethanolic extract of the leaves of pedilanthus tithymaloides and Pupalia Leppacea dissolved in normal saline to prepare dose level of $100,200,400 \mathrm{mg} / \mathrm{kg}$ body weight for administration into rats.

\section{Induction of diabetes}

The animals (male rats) were fasted overnight and diabetes was induced by a single intraperitoneal injection of a freshly prepared solution of Alloxan monohydrate $(150 \mathrm{mg} / \mathrm{kg})$ in ice cold $0.9 \% \mathrm{NaCl}$ saline solution. The animals were given $5 \%$ dextrose solution to drink immediately after induction to overcome the drug induced hypoglycemia. Control rats were injected with normal saline alone. 48 hours later rats with blood glucose level 
(BGL) above $200 \mathrm{mg} / \mathrm{dl}$ were considered diabetic and selected for the experiment.

Table 2: Chemical composition of Pupalia lappacea by GCMS analysis.

\begin{tabular}{|c|c|c|c|c|}
\hline $\begin{array}{l}\text { Retention } \\
\text { time (min) }\end{array}$ & Active constituent & $\begin{array}{l}\text { Molecular } \\
\text { weight }\end{array}$ & $\begin{array}{l}\text { Area } \\
\%\end{array}$ & Therapeutic uses \\
\hline 1.2 & 2,4-Thiazolidinedione & 117 & 32.97 & $\begin{array}{l}\text { Anti diabetic, anti hyperlipidemic, anti } \\
\text { convulsant, cardiotonic }\end{array}$ \\
\hline 1.490 & 3-Pentanone, 2,4-dimethyl- & 114 & 2.10 & \\
\hline 1.538 & 1-Propanol, 2-methyl & 74 & 2.29 & $\begin{array}{l}\text { Hypertension, anxiety, migraine, headache, } \\
\text { angina pectoris, myocardial infarction, } \\
\text { cardiac arrhythmias, heart attack. }\end{array}$ \\
\hline 1.686 & 1-Butanol & 74 & 0.21 & \\
\hline 1.776 & $\begin{array}{l}\text { 2-Pentadecyl-4,4,5,5-tetradeutero-1,3- } \\
\text { dioxolane }\end{array}$ & 284 & 0.23 & Antioxidant activity \\
\hline 1.875 & 2-Propanol, 1,1'-oxybis & 134 & 0.12 & $\begin{array}{l}\text { Hypertension, anxiety, migraine, headache, } \\
\text { angina pectoris, myocardial infarction, } \\
\text { cardiac arrhythmias, heart attack. }\end{array}$ \\
\hline 1.925 & Acetone, ethyl methyl acetal & 118 & 0.13 & Fragrance, flavoring agent, solvent. \\
\hline 2.027 & Ethane, 1,1-diethoxy & 118 & 24.65 & Anti knocking agent for carbureted fuels. \\
\hline 2.126 & 2-PENTENE, 3-METHYL & 84 & 1.46 & Anesthetic \\
\hline 2.301 & Silane, diethoxydimethyl & 148 & 0.89 & Adhesive. \\
\hline 2.358 & Propane, 2,2-diethoxy & 132 & 3.57 & stabilizer, additive. \\
\hline 2.683 & 3-Penten-2-one, 4-methyl & 98 & 0.32 & Synergistic for herbicide, insecticide. \\
\hline 2.834 & Propane, 1,1-diethoxy- & 132 & 0.23 & $\begin{array}{l}\text { Fragrance in cosmetic, perfume, detergent } \\
\text { industries. }\end{array}$ \\
\hline 2.915 & Ethane, 1,1-diethoxy & 118 & 3.51 & Anti knocking agent \\
\hline 3.117 & Formic acid, 1-methylethyl ester & 88 & 0.66 & Anti microbial activity \\
\hline 3.495 & Propane, 1,1-diethoxy-2-methyl & 146 & 0.50 & Anti malarial activity \\
\hline 4.192 & 4-Ethoxy-2-pentanone & 130 & 14.49 & Anti bacterial, anti viral agent, \\
\hline 4.525 & $\mathrm{CH} 3 \mathrm{CH}(\mathrm{OH}) \mathrm{CH} 2 \mathrm{C}(\mathrm{O}) \mathrm{CH} 3$ & 102 & 0.03 & Catalytic activity. \\
\hline 5.344 & Butane, 1,1-diethoxy-3-methyl & 160 & 0.41 & $\begin{array}{l}\text { Spasmolytic, coronary dilation, local } \\
\text { anesthetic }\end{array}$ \\
\hline 17.534 & Hexadecane & 226 & 0.45 & Emulsifying agent. \\
\hline 20.042 & Heptadecane & 240 & 0.75 & Solvent \\
\hline 22.666 & Heptadecane & 240 & 2.97 & Solvent \\
\hline 24.567 & Undecane, 5-methyl- & 170 & 0.06 & Anti asthamatic, anti cancer \\
\hline 25.627 & Heptadecane & 240 & 2.21 & Solvent \\
\hline 25.810 & Pentadecane, 2,6,10,14-tetramethyl- & 268 & 0.51 & \\
\hline 27.117 & $\begin{array}{l}\text { Cyclohexane, 1,1'-[1-(2,2-dimethylbutyl)- } \\
\text { 1,3-propanediyl]bis- }\end{array}$ & 292 & 0.23 & $\begin{array}{l}\text { Plant growth regulating effects in crop and } \\
\text { non crop plants }\end{array}$ \\
\hline 27.208 & 2,6,6-Trimethyl-bicyclo & 153 & 0.12 & Insecticides, pesticides. \\
\hline 28.270 & Eicosane & 282 & 2.07 & $\begin{array}{l}\text { Anti bacterial and anti fungal in } \\
\text { pharmaceutical cosmetic and food industries. }\end{array}$ \\
\hline 30.689 & Nonadecane & 268 & 0.28 & $\begin{array}{l}\text { Additive, arthritis, rheumatism, gingivitis, } \\
\text { periodontal. }\end{array}$ \\
\hline 32.077 & Oxiranecarboxamide, 2-ethyl-3-propyl & 157 & 0.11 & Hyperlipidimia by lipogenesis inhibition. \\
\hline 32.882 & Hexadecane & 226 & 0.49 & Emulsifying agent. \\
\hline 35.921 & Cyclohexane & 292 & 0.22 & \\
\hline 36.125 & Beta-Ionone Epoxide & 208 & 0.16 & $\begin{array}{l}\text { Flavoring agent, fragrance agent in } \\
\text { pharmaceutical and agricultural industries }\end{array}$ \\
\hline 36.300 & Cyclohexanol, 2-methyl-, cis & 114 & 0.03 & $\begin{array}{l}\text { Centrally acting analgesic, trigeminal } \\
\text { neuralgia. }\end{array}$ \\
\hline 41.933 & 2-Nonynoic acid & 154 & 0.03 & \\
\hline 42.956 & $\begin{array}{l}\text { 1,2-Benzenedicarboxylic acid, dioctyl } \\
\text { ester }\end{array}$ & 390 & 0.42 & $\begin{array}{l}\text { Radio labeling agent, synthesis of dyes, } \\
\text { perfume and other organic compounds, anti } \\
\text { androgen. }\end{array}$ \\
\hline 43.058 & 5-cis-Methyl-1R,3-cis-cyclohexanediol & 130 & 0.07 & Highly active pesticides. \\
\hline
\end{tabular}




\section{Grouping treatment}

Groups 2, 3, 4, 5 and 6 will be induced diabetes by i.p route using alloxan monohydrate $(150 \mathrm{mg} / \mathrm{kg} \mathrm{b} . \mathrm{w})$. The diabetic state of animals is then checked and confirmed. Animals becomes diabetic if their blood glucose level is $217 \pm 17 \mathrm{mg} / \mathrm{dl}$.

Collection of blood for determination of blood glucose level

Blood samples were drawn from tail tip of rat at weekly intervals till the end of study (i.e., 3 weeks). Fasting blood glucose estimation and body weight measurement were done on day 1,7 , and 14 and 21 of the study. Blood glucose estimation can be done by one touch electronic glucometer using glucose test strips. On day 21 , blood was collected from retro-orbital plexus under mild ether anesthesia from overnight fasted rats and fasting blood sugar was estimated. Serum was separated and analyzed for following parameters. Blood glucose level, Total cholesterol, Triglycerides, High density lipoprotein (HDL), Low density lipoprotein (LDL), very low density lipoprotein (VLDL), cholesterol ratio were estimated by standard methods.

\section{RESULTS}

In toxicity studies, ethanolic leaf extract of Pupalia lappaceae did not exhibit any mortality and abnormal behavioural changes upto the dose level of $200 \mathrm{mg} / \mathrm{kg}$ b.w in rats. Hence the pharmacological studies were carried out at an oral dose of 100, 200 and 400mg/kgb.w.

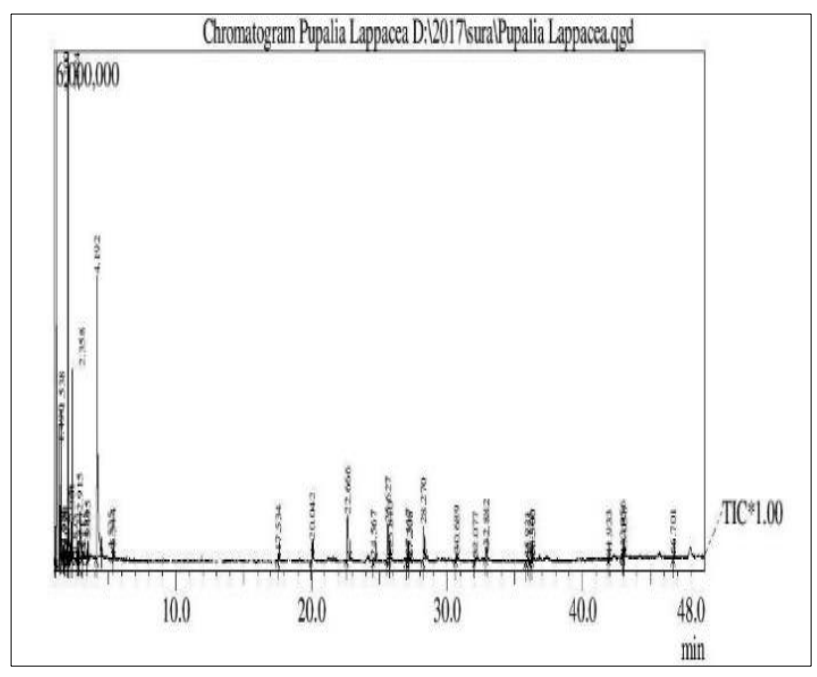

Figure 2: Chromatogram of Pupalia lappacea by GCMS analysis.

Values are given as \pm SEM for group of six animals in each group.

- Group II: Diabetic control rats were compared with normal rats.
- $\quad$ Group III: Diabetic +glibenclamide and simvastatin $(5 \mathrm{mg} / \mathrm{kg})$ were compared with diabetic control rats, Group IV: Diabetic + AEPL (100mg/kg) b.w,

- Group V: Diabetic +AEPL (200mg/kg) b.w,

- Group VI: Diabetic + AEPL (400mg/kg) b.w,

- Group VII: Diabetic +EEPL (100mg/kg.b.w),

- Group VIII: Diabetic +EEPL (200mg/kg.b.w),

- Group IX: Diabetic +EEPL (400mg/kg.b.w) were compared with diabetic control rats.

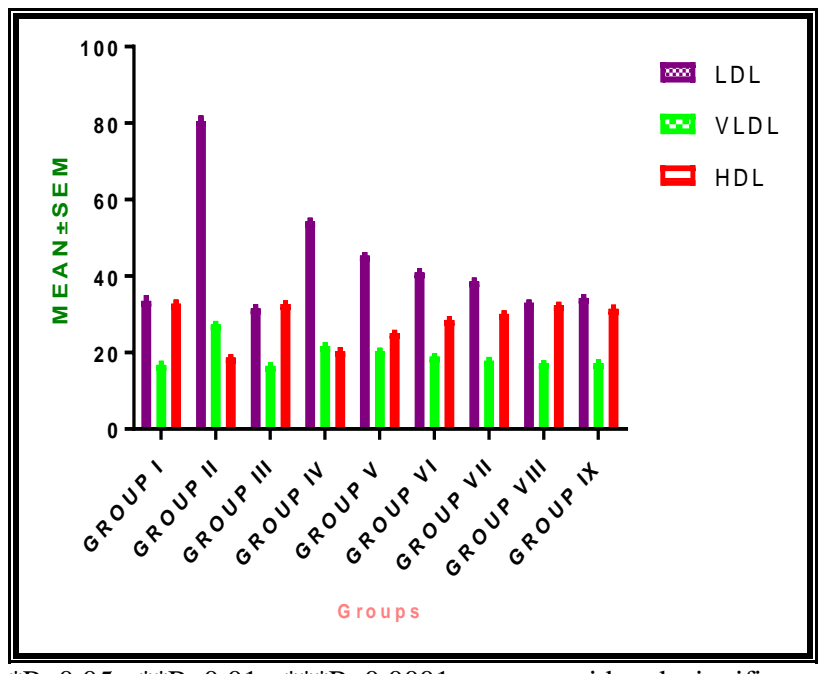

$* \mathrm{P}<0.05, * * \mathrm{P}<0.01, * * * \mathrm{P}<0.0001$ was considered significant comparing to diabetic control group.

Figure 3: Serum lipid profile of PL.

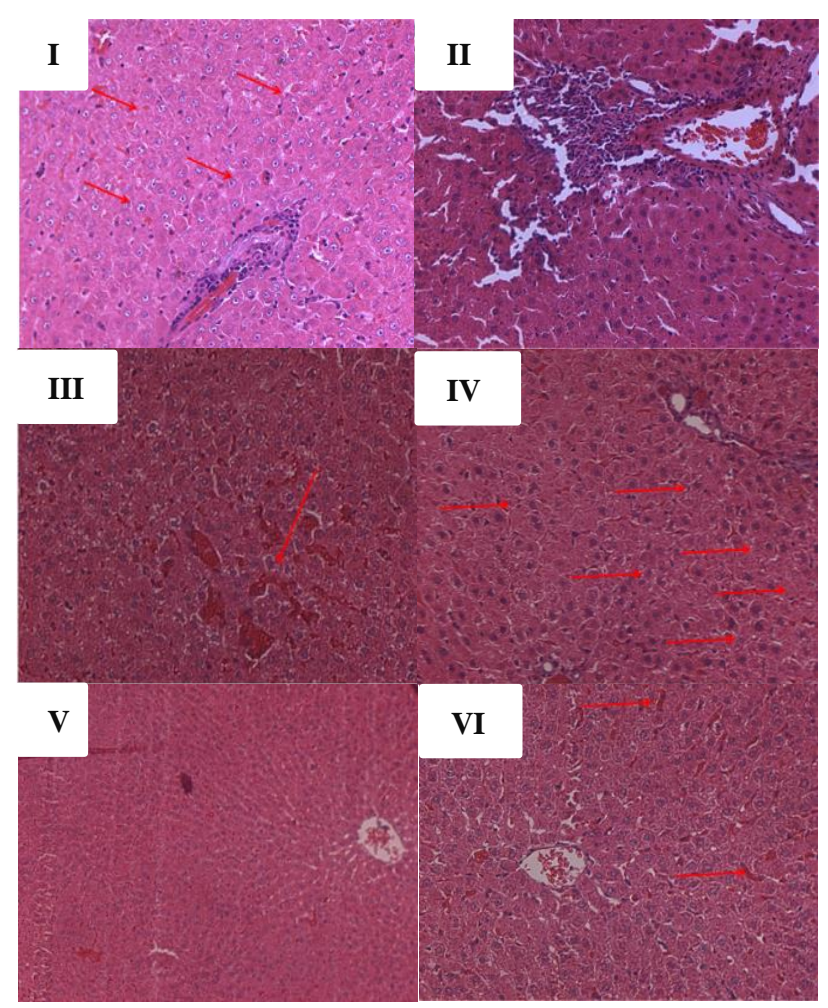

Figure 4: Histopathological studies of liver (Groups I, II, III, IV, V, VI). 
Table 3: Effect of ethanolic extracts of the leaves of medicinal plants on blood glucose levels (mg/dl) in alloxan induced diabetic rats on $1^{\text {st }}, 7^{\text {th }}, 14^{\text {th }}$ and $21^{\text {st }}$ day of treatment.

\begin{tabular}{|lllll|}
\hline Groups & 1st day & $7^{\text {th }}$ day & $\mathbf{1 4}^{\text {TH }}$ day & $\mathbf{2 1}^{\text {ST }}$ day \\
\hline I & $87.50 \pm 0.309$ & $87.30 \pm 0.264$ & $89.50 \pm .242$ & $87.5 \pm 0.392$ \\
\hline II & $228.3 \pm 0.226$ & $238.2 \pm 0.288$ & $265.8 \pm 0.285$ & $281 \pm 0.423$ \\
\hline III & $216.7 \pm 0.311$ & $154.6 \pm 0.278$ & $130.3 \pm 0.211^{* *}$ & $120.7 \pm 0.274 * * *$ \\
\hline IV & $218.5 \pm 0.777$ & $205.3 \pm 0.275$ & $196.5 \pm 1.086^{*}$ & $178.9 \pm 0.244^{*}$ \\
\hline V & $226.3 \pm 0.784$ & $195.8 \pm 1.875$ & $185.5 \pm 0.243^{*}$ & $180.5 \pm 0.026^{* *}$ \\
\hline VI & $220.6 \pm 0.712$ & $184.5 \pm 0.182$ & $168.5 \pm 1.004^{* *}$ & $165.5 \pm 0.06^{* *}$ \\
\hline VII & $219.5 \pm 1.013$ & $179.8 \pm 0.512$ & $175.3 \pm 0.250^{* *}$ & $150.6 \pm 2.184 * *$ \\
\hline VIII & $220.9 \pm 0.137$ & $159.5 \pm 0.615$ & $138.5 \pm 1.999^{* *}$ & $123.6 \pm 1.466^{* *}$ \\
\hline IX & $222.9 \pm 0.235$ & $168.9 \pm 0.274$ & $130.8 \pm 1.651^{* *}$ & $145.5 \pm 2.249 * * *$ \\
\hline & $\bullet$ & Values are given as \pm SEM for group of six animals in each group. & \\
\hline
\end{tabular}

Table 4: Effect of ethanolic and aqueous extract of Pupalia lappacea on serum lipid profile in alloxan induced diabetic rats after 21 days of treatment.

\begin{tabular}{|llll|}
\hline Groups & LDL & VLDL & HIDL \\
\hline I & $33.5 \pm 0.763$ & $16.80 \pm 0.325$ & $32.83 \pm 0.279$ \\
\hline II & $80.50 \pm 0.76$ & $27.34 \pm 0.202$ & $18.67 \pm 0.213$ \\
\hline III & $31.5 \pm 0.343 * * *$ & $16.5 \pm 0.303 * * *$ & $32.67 \pm 0.232 * * *$ \\
\hline IV & $54.33 \pm 0.208^{*}$ & $21.69 \pm 0.300^{*}$ & $22.39 \pm 0.346^{*}$ \\
\hline V & $45.36 \pm 0.212^{* *}$ & $20.36 \pm 0.199^{* *}$ & $25.09 \pm 0.149 * *$ \\
\hline VI & $40.96 \pm 0.385^{* *}$ & $18.95 \pm 0.164 * *$ & $28.5 \pm 0.297 * *$ \\
\hline VII & $38.6 \pm 0.251^{* *}$ & $17.9 \pm 0.216^{* *}$ & $30.1 \pm 0.150 * *$ \\
\hline VIII & $34.33 \pm 0.214 * *$ & $17.3 \pm 0.211^{* *}$ & $31.49 \pm 0.289 * *$ \\
\hline IX & $33 \pm 0.154 * * *$ & $17.2 \pm 0.129 * * *$ & $32.35 \pm 0.168 * * *$ \\
\hline
\end{tabular}

$* \mathrm{P}<0.05, * * \mathrm{P}<0.001, * * * \mathrm{P}<0.0001$ was considered significant comparing to diabetic control group.

\section{Histopathological studies of liver}

\section{- Group I (Liver)}

Individual hepatocytes appeared normal in portal, periportal and centri lobular region of liver - Arrow

\section{- $\quad$ Group II (Liver)}

Foci of inflammation noticed in centri lobular region of liver - Arrow

Moderate foci of inflammation noticed in Perivascular region of liver - Arrow

\section{- $\quad$ Group III (Standard)}

Mild sinusoidal hemorrhages noticed in the liver - arrow

\section{- $\quad$ Group IV (EEPL 100mg/kg b.w)}

Individual hepatocytes appeared normal in portal, periportal and centri lobular region
But mild sinusoidal hemorrhages noticed in the sinusoidal spaces in the liver - Arrow

\section{- $\quad$ Group V liver (EEPL 200mg/kg b.w.)}

Individual hepatocytes appeared normal in portal, periportal and centri lobular region - Arrow

\section{- $\quad$ Group VI liver (EEPL 400mg/kg b.w.)}

Individual hepatocytes appeared normal in portal, periportal and centri lobular region - Arrow

Table 5: Effect of ethanolic and aqueous extract of Pupalia lappacea on TC, TRG, CR in alloxan induced diabetic rats after 21 days of treatment.

\begin{tabular}{|llll|}
\hline Groups & $\begin{array}{l}\text { Total } \\
\text { cholesterol }\end{array}$ & $\begin{array}{l}\text { Total } \\
\text { triglycerides }\end{array}$ & $\begin{array}{l}\text { Cholesterol } \\
\text { ratio }\end{array}$ \\
\hline I & $81.84 \pm 0.164$ & $83.5 \pm 0.483$ & $2.35 \pm 0.189$ \\
\hline II & $126.83 \pm 0.623$ & $132.33 \pm 0.590$ & $6.44 \pm 0.294$ \\
\hline III & $82 \pm 0.186 * * *$ & $85 \pm 0.371 * * *$ & $2.5 \pm 0.150 * * *$ \\
\hline IV & $101.39 \pm 0.23 * 3$ & $108.45 \pm 0.33 * 8$ & $4.702 \pm 0.158 *$ \\
\hline V & $89.4 \pm 0.256 * *$ & $101.8 \pm 0.249 * *$ & $3.813 \pm 0.177 * *$ \\
\hline VI & $86.02 \pm 0.199 * *$ & $94.75 \pm 0.224 * *$ & $3.35 \pm 0.120 * *$ \\
\hline VII & $86.45 \pm 0.204 * *$ & $89.5 \pm 2.220 * *$ & $2.935 \pm 0.220 * *$ \\
\hline VIII & $81.5 \pm 3.047 * *$ & $85.5 \pm 0.329 * *$ & $2.54 \pm 0.659 * *$ \\
\hline IX & $84.3 \pm 1.699 * * *$ & $86.5 \pm 0.923 * * *$ & $2.78 \pm 0.529 * * *$ \\
\hline
\end{tabular}

$* \mathrm{P}<0.05, * * \mathrm{P}<0.001, * * * \mathrm{P}<0.0001$ was considered significant comparing to diabetic control group.

\section{Histopathological studies of pancreas}

- $\quad$ Group I pancreas

Ductular pancreas appeared normal - Arrow

- Group II pancreas (Diabetic control)

Individual beta cell necrosis or apotosis leads to atrophy of glandular pancreas - Arrow 
- $\quad$ Group III pancreas (Standard)

Beta cells in islets of pancreas or glandular pancreas appeared normal - Red arrow

- $\quad$ Mild proliferation of beta cells noticed

Acinar cells in non glandular region appeared normal Green arrow

- $\quad$ Group IV pancreas (EEPL 100mg/kg b.w.)

Moderate proliferation of beta cells in islets of pancreas glandular pancreas indicate the active regeneration of islets cells initiated - Arrow

\section{- $\quad$ Group V (EEPL 200mg/kg b.w.)}

Moderate proliferation of beta cells in islets of pancreas glandular pancreas indicate the active regeneration of islets cells initiated - Red arrow

Acinar cells in non glandular region appeared normal green arrow

- $\quad$ Group VI Pancreas (EEPL 400 mg/kg b.w.

Midl hemorrhages noticed in glandular pancreas - islet of pancreas but the islets cells appeared normal - Arrow.

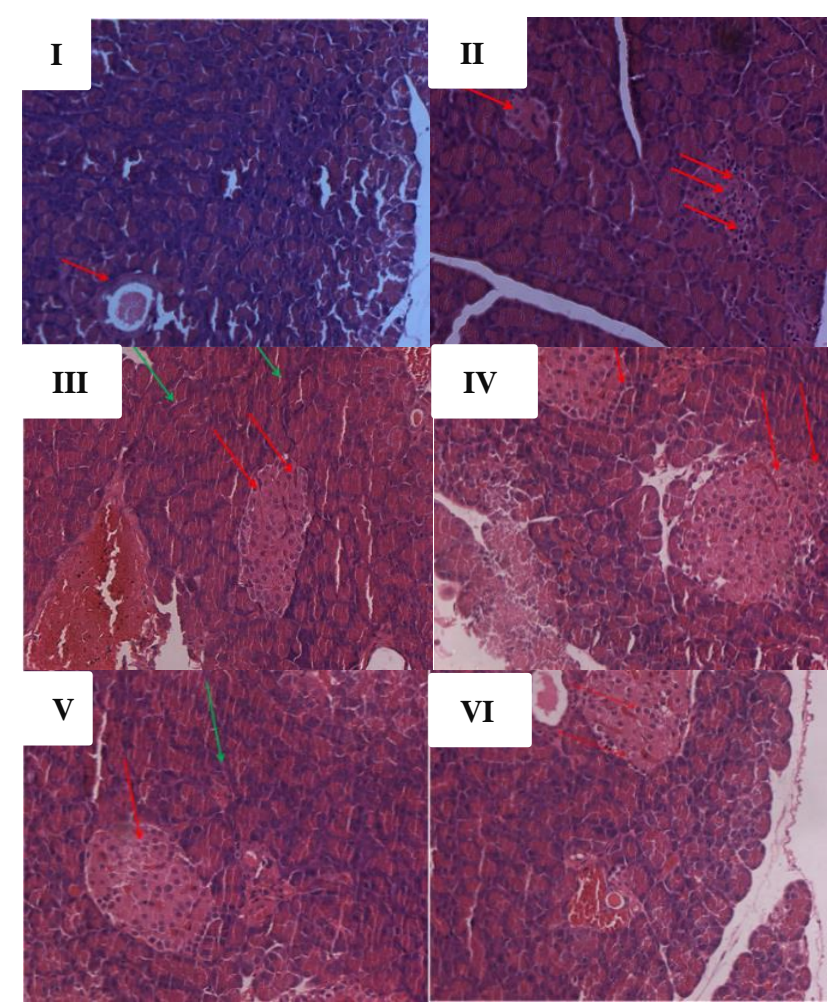

Figure 5: Histopathological studies of Pancreas [Group I (N.C), Group II (DC), Group III (STD), Group IV (EEPL 100mg/kg), Group V (EEPL200mg/kg), Group VI (EEPL400mg/kg)].

\section{Histopathological studies of kidney}

- Group I: Glomerulus appeared normal - Arrow

No degenerative and inflammatory changes noticed

- $\quad$ Group II: Nephrons were destroyed completely

- Group III: glomerulus was normal

- $\quad$ Group IV kidney (EEPL $100 \mathrm{mg} / \mathrm{kg}$ b.w.)

Mild infiltration of lymphocytes noticed in Perivascular region of kidney - arrow

- $\quad$ Group V kidney (EEPL 200mg/kg b.w.)

Glomerulus appeared normal - Arrow

No degenerative and inflammatory changes noticed

- $\quad$ Group VI kidney (EEPL 400mg/kg b.w.)

Glomerulus appeared normal - Red arrow

Tubular region appeared normal - Black arrow.

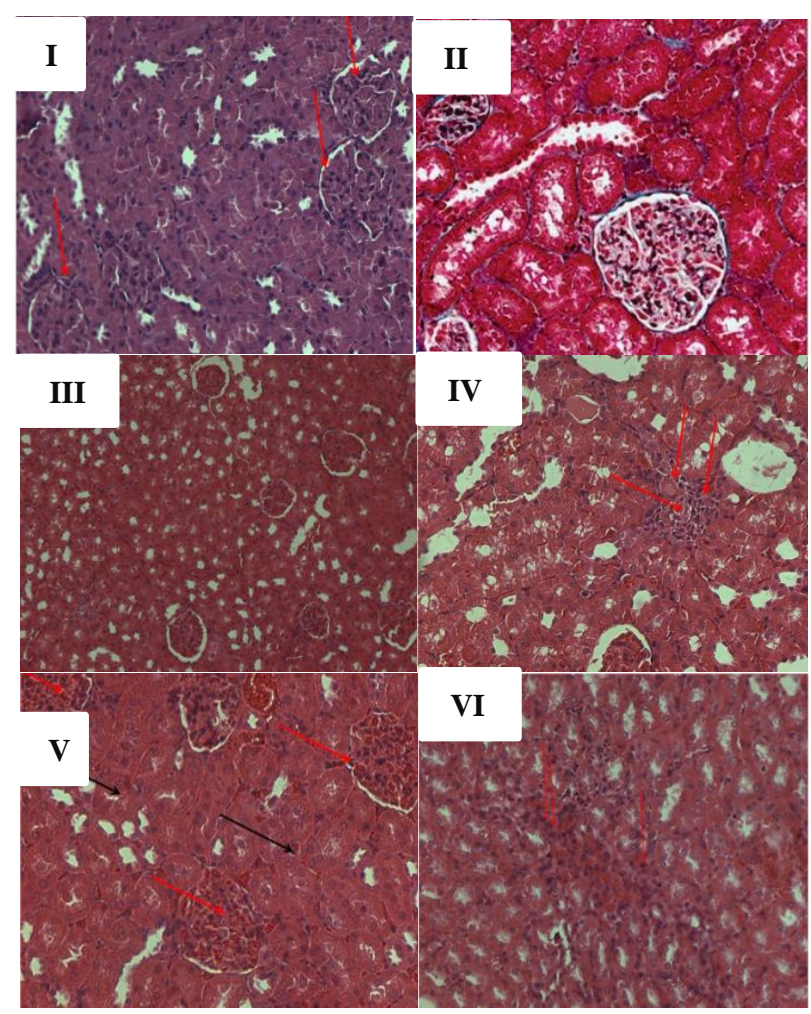

Figure 6: Histopathological studies of kidney [Group I (N.C) Group II (D.C) Group III(STD), Group IV (EEPL100mk/kg) Group V (EEPL200mg/kg) Group VI (EEPL400mg/kg)]. 


\section{DISCUSSION}

In the present work, we investigated the hypoglycemic, anti hyperlipidemic property of the ethanolic and aqueous leaf extract of leaves of Pupalia lappacea in the alloxan induced diabetic animal model. Chemical substances also cause diabetes in experimental models. These includes substances such as alloxan and streptozotocin. In the present study alloxan is used as a diabetomimetic in mice. Alloxan causes diabetes through its ability to destroy the insulin-producing beta cells of the pancreas. The ethanolic and aqueous extracts of leaves of Pupalia lappacea was tested on laboratory animals.

In the present study, the administration of Pupalia lappacea leaf extracts to alloxan induced hyperglycemic rats demonstrated prominent reduction in blood sugar level the results are plotted in Table 3, normalization of serum biochemical profile including lipid content, cholesterol, as compared to alloxan control rats the results were plotted in Table 4 and Table 5. The phytochemical analysis has shown the presence of potent phytochemicals such as flavonoids, terpenoids, glycosides, steroids, saponin and phenols the results were tabulated in Table 1. This study revealed the presence of chemical composition of EEPL ethanolic extract by GCMS analysis. The results were tabulated in Table 2.

\section{CONCLUSION}

The present study shows that the etanolic leaf extract of Pupalia lappacea is effective in the treatment of diabetes. Diabetes was induced in rats by alloxan monohydrate at dose of $150 \mathrm{mg} / \mathrm{kg}$ body weight injected intraperitoneally. The animals were kept under observation. After $48 \mathrm{hr}$ the animal were tested for glucosurea using strips. The blood glucose level was checked before and after $72 \mathrm{hr}$ after alloxan injection to confirm the development of diabetes. At the end of the administration period, i.e 21 days, the rat was anaesthetized and dissect for the collection of blood and liver tissues. Serum was evaluated for the estimation of glucose, LDL, VLDL, HDL, cholesterol, triglycerides.

The results from this study indicated that ethanolic and aqueous leaf extract of Pupalia lappacea had hypoglycemic effects in alloxan induced diabetic mice, thus scientifically verifying its use in the management of diabetes mellitus. These actions were exhibited due to phytoconstituent present in the extract like flavonoids.

Funding: No funding sources Conflict of interest: None declared

Ethical approval: The study was approved by the Institutional Ethics Committee

\section{REFERENCES}

1. Rao KB, Giri R, Kesavulu MM, Apparao CH. Herbal medicine in the management of diabetes mellitus. Manphar Vaidhya Patrika. 1997;1(4):5.

2. Oliver-Bever IS. Medicinal plants in tropical West Africa. Cambridge university press; 1986 Jan 23

3. Kala, Chandra Prakash. Sajwan. Revitalizing Indian systems of herbal medicine by the National Medicinal Plants Board through institutional networking and capacity building. Current Science. 2007;93(6):797806.

4. Acharya D, Shrivastava K. Indigenous Herbal Medicines-Tribal Formulation and traditional herbal practices. India: Aavishkar Publishers Distributor; 2008.

5. Islam MA, Akhtar MA, Islam MR, Hossain MS, Alam MK, Wahed MI, Rahman BM Anisuzzaman AS, Shaheen SM, Ahmed M. Antidiabetic and hypolipidemic effects of different fractions of Catharanthus roseus (Linn.) on normal and streptozotocin-induced diabetic rats. Journal of Scientific Research. 2009 Apr 23;1(2):334-44.

6. Holman RR, Turner RC, Textbook of Diabetes Blackwell, Oxford; 1991:345-356.

7. Murthy BK, Nammi S, Kota MK, Rao RK, Rao NK, Annapurna A. Evaluation of hypoglycemic and antihyperglycemic effects of Datura metel (Linn.) seeds in normal and alloxan-induced diabetic rats. Journal of ethnopharmacology. 2004 Mar 31;91(1):95-8.

8. Islam MA, Akhtar MA, Islam MR, Hossain MS, Alam MK, Wahed MI, et al. Antidiabetic and hypolipidemic effects of different fractions of Catharanthus roseus (Linn.) on normal and streptozotocininduced diabetic rats. Journal of Scientific Research. 2009 Apr 23;1(2):334-44.

9. Yokozawa T, Ishida A, Cho EJ, Nakagawa T. The effects of Coptidis Rhizoma extract on a hypercholesterolemic animal model. Phytomedicine. 2003 Jan 1;10(1):17-22.

10. Mahley RW, Bersot TP. Drug therapy for hypercholesterolemia and dyslipidemia. Goodman and Gilman's the pharmacological basis of therapeutics. 10 $0^{\text {th }}$ Ed. New York: McGraw Hill; 2001:971-1002.

11. Khandelwal KR. Practical Pharmacognosy Techniques and experiments; 19 ${ }^{\text {th }}$ Edition, Pune: Nirali Prakashan; 2008:149-160.

12. No OT. 423: acute oral toxicity-acute toxic class method. OECD guidelines for the testing of chemicals (section 4: health effects). 2001:1-4.

Cite this article as: Farheen M, Chakrapani R. Phytochemical evaluation and pharmacological screening of ethanolic and aqueous leaf extracts of Pupalia lappacea for antihyperlipidemic and antihyperglycemic activities in alloxan induced diabetic Albino wistar rats. Int J Basic Clin Pharmacol 2018;7:753-60. 